\title{
THE MEDIATING EFFECT OF PROACTIVE KNOWLEDGE SHARING AMONG TRANSFORMATIONAL LEADERSHIP, COHESION, AND LEARNING GOAL ORIENTATION ON EMPLOYEE PERFORMANCE
}

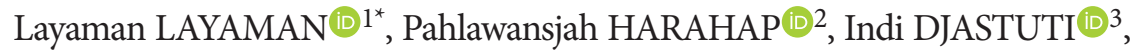 \\ Aan JAELANI ${ }^{4}$, Diana DJUWITA (1) 5 \\ 1, 4, 5 Department of Sharia Economics, State Islamic Institute (IAIN) Syekh Nurjati Cirebon, Indonesia \\ ${ }^{2}$ Department of Management Sciences, Faculty of Economics and Business, University of Semarang, Indonesia \\ ${ }^{3}$ Department of Management Sciences, Faculty of Economics and Business, University of Diponegoro, Indonesia
}

Received 14 August 2020; accepted 24 June 2021

\begin{abstract}
The background of this study is based on the controversial relationship between transformational leadership and employee performance. Empirical and theoretical models resolve the controversy by building a new concept based on proactive knowledge sharing. The study established the influence of transformational leadership, cohesion and learning goal orientation on proactive knowledge sharing and employee performance. A total of 7 hypotheses were developed to solve the study problem, while purposive sampling was used in data collection. The respondents consisted of 6 employees of Sharia Banking in Indonesia. The SEM results indicate that five hypotheses were significant, while 2 were insignificant. Furthermore, proactive knowledge sharing strongly mediates the relationship between the studied variables. These results confirm the withdrawal of the new concept in improving employee performance.
\end{abstract}

Keywords: transformational leadership, learning goal orientation, proactive knowledge sharing, employee performance.

JEL Classification: M2, A1, O3.

\section{Introduction}

Front-line employees' performance is crucial in the highly competitive service sector (Cooke et al., 2019). Studies have been conducted to determine the pointers by investigating various variables in the literature. For instance, previous research identified leader behavior as a critical factor in influencing front-line employees' performance. The success of services and people-oriented businesses, such as the banking sector, highly depends on management (Terglav et al., 2016). Theoretically, research shows that leaders significantly impact performance outcomes in different cultures (Sarwar et al., 2020) and financial institutions (Asrar-ul-Haq \& Kuchinke, 2016). Transformational leadership style may change individuals when leaders and subordinates interact to increase their motivation and morality. Studies show that transformational leadership increases adaptability and proactive employees in the workplace (Wang et al., 2017).

A previous research review shows inconsistency in the mechanism explaining the influence of leadership and organizational learning on performance. For instance, several studies show that transformational leadership significantly influences follower performance (Buil et al., 2019; Ribeiro et al., 2018; Obeidat \& Tarhini, 2016; Asrar-ul-Haq \& Kuchinke, 2016; Cavazotte et al., 2013; Sundi, 2013; Carter et al., 2013; Ghafoor et al., 2011). However, Charlton and Eschleman (2019), Eliyana and Ma'arif (2019), Tahir (2015), Chen et al., 2014, Insan et al., 2013, Paracha et al. (2012), Obiwuru et al. (2011), Brown and Arendt (2010) show no effect of transformational leadership on employee performance. This allows the exploitation of the mediating factors' role in explaining the achievement of the organization's desired goals.

Previous studies show that knowledge management mediates the influence of leadership and learning organization on performance. Furthermore, knowledge management mediates the influence of organizational context on organizational effectiveness (Aldulaimi, 2015). Therefore, this study develops another mechanism on how transformational leadership improves employee performance through knowledge sharing. Modern researchers stressed that knowledge sharing is essential in organizational

*Corresponding author. E-mail: layaman72@gmail.com 
effectiveness and contributes to business success (Akram \& Bokhari, 2011).

Previous studies noted the importance of knowledge as a priceless company asset (Sokól, 2020) and a force that drives business success (Zeraati et al., 2019). There is a contradiction in findings in Indonesia that $93.22 \%$ of Islamic Bank employees lack Sharia knowledge. This is evident in the educational background of employees (Yusuf et al., 2017). Knowledge is extensive, such as an unbroken ocean or spring that is valuable to the organization (Javadi et al., 2012). Therefore, knowledge enables the organization to survive the competition and achieve a competitive advantage (Quartey, 2019). Therefore, an organization's survival power depends on knowledge use. For this reason, organizations proactively seek and disseminate new knowledge to all their units.

\section{Literature review and hypothesis development}

Knowledge management involves the practice of sharing knowledge (Donate \& de Pablo, 2015). Also, it is essential in improving individual abilities in new learning resources and data, problem-solving, self-improvement (Din \& Haron, 2012), and knowledge exchange between individuals and business units (Ganguly et al., 2019). Knowledge sharing comprises behaviors regarding knowledge exchange involving actors, organizational context, content, social environment, and appropriate media. The knowledge-sharing model is conceptualized into transmission and absorption (Nguyen et al., 2019; Yang \& Chen, 2007). When new knowledge is obtained, it must be transferred to another part of the organization to be more helpful. The business success of knowledge sharing is related to technological and behavioral factors.

New knowledge is created and shared by companies through a soft mode connecting tacit and explicit knowledge. Tacit knowledge is shared through socialization, a process of sharing experiences through technical skills and mental models. The knowledge is transferred among people through mentoring and modelling, work culture, conversation, and experience sharing. This is an externalization process that converts tacit into explicit knowledge. Companies achieve this using analogies, metaphors, models, or concepts, and it takes place between individuals within a group (Ganguly et al., 2019).

Internalization converts explicit knowledge generated by others to tacit knowledge, which is then absorbed and internalized. Individuals internalize the experience acquired through socialization, externalization and combination based on tacit knowledge sharing through technical skills or mental models. Organizations transfer internalization and tacit knowledge, followed by employees (Bashir \& Farooq, 2019). The combination process creates new concepts by merging two explicit knowledge sources. An example is when several reports are integrated into a completely new report into a database or knowledge base or database. The combination allows the transfer of knowledge between groups throughout the organization (Bradshaw et al., 2015).

\subsection{Proactive knowledge sharing}

Proactive knowledge sharing (PKS) integrates proactiveness as extra-role dimensions (Van Dyne \& LePine, 1998; Grant et al., 2011) and knowledge sharing based on the learning orientation dimensions (Calantone et al., 2002; Nybakk, 2012). PKS is the knowledge transfer of the organization's members through an active exchange of explicit and implicit knowledge to improve work performance. Therefore, PKS has the potential to improve employee performance.

\subsection{Transformational leadership}

Burns (1978) described a transformational leader as someone that full involves and develops subordinates' potential, and meets the needs of a higher level. This concept differs from the transactional approach that portrays leadership as a mutual relationship between leaders and followers, such as the exchange of rewards for desirable behavior. Therefore, Bass (1995) developed Transformational Leadership (TL) as a process that increases followers' awareness regarding the problem of consequences, influences subordinates to forego personal interests for the group's good, and motivates them to work beyond expectations (Bass, 1999). Furthermore, according to Bass, this leadership style motivates others to work more than expected and even more, than they think. The leader achieves higher performance by setting more challenging expectations. This study defined TL as a proactive leader that increases follower awareness to transcend collective interests and achieve extraordinary goals (Antonakis et al., 2003).

\subsection{Cohesion}

Cohesion $(\mathrm{COH})$ is the unity between members of a group pursuing instrumental objectives and satisfying their affective needs (Carron et al., 1998). Group cohesion is a multi-concept, including task and social cohesion, a view widely accepted among many researchers (Tung et al., 2019). Task cohesion comprises the motivation towards achieving group goals (Heuzé et al., 2006) and commitment to those goals (Zaccaro \& Lowe, 1988). Social cohesion is motivation by the group members to develop and maintain social relations (Heuzé et al., 2006).

\subsection{Learning goal orientation}

Goal orientation is divided into learning and performance goal orientation (Sujan et al., 1994; VandeWalle, 2003; DeShon \& Gillespie, 2005; Kim \& Lee, 2013). Learning goal orientation (LGO) concerns an individual's willingness to continue learning to gain new knowledge and improve work skills. Performance goals orientation is the tendency of an individual to show their competence to others. 


\subsection{Employee performance}

Performance is a multidimensional concept divided into task and contextual performance (Borman et al., 2001). Task performance is an individual's proficiency in executing the tasks contributing to the work's technical core. Contextual performance is a work activity unrelated to the technical core but supports the organization in achieving goals. Here are some concepts of employee performance and indicators used in their measurement.

Job performance is essential in employee management. Employee performance (EP) is the employees' ability to realize individual goals, meet expectations and achieve targets or organizational standards (June \& Mahmood, 2011). Therefore, EP consists of employees' abilities and natural or acquired skills and motivation to improve results.

\subsection{Hypotheses}

\subsubsection{Transformational leadership and proactive knowledge sharing}

Leaders play an essential role in knowledge sharing through TL behavior. For instance, transformational leaders improve the shared vision and provide the necessary structures or systems, motivation, and knowledge sharing willingness (Akpotu \& Tamunosiki-Amadi, 2013). Furthermore, leaders create a customized model of employees' willingness to share their knowledge, continue to learn and search for new ideas (Wong, 2005). Leaders create a climate that enables and facilitates knowledge sharing (Salo, 2011).

TL creates and delivers new information to employees during knowledge sharing (Lee et al., 2010). As a result, they enable better collaboration and support among fellow employees (Mabey et al., 2012). Moreover, TL increases knowledge transfer and utilization, enhance the establishment of responsibilities and rewards system, improve employee skills, encourage adaptation to the strategic objectives, and support quality communication among employees (Baytok et al., 2014). Therefore, TL is a vital facilitator and determinant of knowledge sharing practices (Chen \& Barnes, 2006). A transformational leader is a proactive leadership because they encourage knowledge sharing and articulate a shared vision. Additionally, they provide a suitable model, encourage adaptation to the group's goals, inspire employees, support innovative ideas, build systems and culture, and participate in knowledge sharing. According to (Yadav et al., 2019; Khan \& Khan, 2019), TL influenced knowledge collecting and donating behavior. Based on the description, the hypothesis is formulated:

H1: Transformational leadership influences proactive knowledge sharing.

\subsubsection{Transformational leadership and cohesion}

Transformational leadership behavior should deliver performance, meaning that $\mathrm{COH}$ is essential in group management. Moreover, transformational leaders help group members redesign personal values based on their vision and goals. This results in more vital values in internalization, cooperation and harmony between the followers (Shamir et al., 1993). Consequently, a shared vision develops, which increases group work cohesion. Vision accompanied by a solid group identity helps transformational leaders in empowering members to achieve goals without being monitored. Furthermore, high collectivity improves the working group cohesiveness among team members. Empirical research found that TL behavior makes employees accept group goals and improve teamwork, highperformance expectations, and individual considerations. This makes employees predict task cohesion and accept group goals, while promoting teamwork helps them predict social cohesion (Callow et al., 2009). Group cohesion enables members to identify where to direct their efforts to achieve their common goal. Various empirical studies show that TL affects $\mathrm{COH}$ (Cronin et al., 2015). Therefore, this study aimed at finding a positive relationship between $\mathrm{TL}$ and $\mathrm{COH}$, resulting in the following hypothesis:

H2: Transformational leadership influences cohesion.

\subsubsection{Transformational leadership and employee performance}

Leadership significantly influences the organization's performance, the management, and employees (Wang et al., 2005). There is extensive scientific research on the relationship between performance and leadership. Studies on the relationship between transactional leadership and organizational performance have disappointing results. However, using the Multifactor Leadership Questionnaire (MLQ), Bass (1985) found a significant correlation between TL style and organizational performance. These correlations were consistently higher than the organizational performance and transactional leadership.

Most studies on the relationship between TL and EP are positive and strong enough (Buil et al., 2019; Ribeiro et al., 2018; Obeidat \& Tarhini, 2016; Asrar-ul-Haq \& Kuchinke, 2016; Cavazotte et al., 2013; Sundi, 2013; Carter et al., 2013; Ghafoor et al., 2011). The results show that a transformational leader inspires subordinates towards having the organization's vision, mission, and goals. Moreover, the leader encourages and motivates subordinates for maximum performance, stimulates them to act and solve problems critically, and treats employees individually. As a result, subordinates respond by working to their maximum.

Therefore, the hypothesis is formulated:

H3: Transformational leadership influences employee performance.

\subsubsection{Learning goal orientation and proactive knowledge sharing}

Learning Goal Orientation (LGO) is the desire for selfdevelopment by mastering new situations, acquiring new skills, and increasing competence (Matsuo, 2019). Orientation is the view that underlies thought. Something held 
in mind cannot immediately lead to performance. LGO is related to various behaviors and adaptive thoughts, such as perceiving failure as an experience for learning, surviving difficulties, setting high goals, and maintaining a high self-efficacy (Payne et al., 2007). Therefore, people with high LGO are actively involved in knowledge sharing. This is because necessary knowledge and skills help them in performing the tasks that facilitate performance. For instance, LGO increased innovative performance through knowledge sharing as a mediator (Lu et al., 2012). Also, learning orientation has a positive influence on knowledge sharing (Matzler \& Mueller, 2011). Employees oriented towards learning goals improve their personal goals with time due to their desire to challenge themselves and are proactive in sharing knowledge. Therefore, the hypothesis is formulated:

H4: Learning goal orientation influences proactive knowledge sharing.

\subsubsection{Cohesion and proactive knowledge sharing}

Cohesiveness is something interesting that should feature in a team (Amabile et al., 2004). A cohesive team allows members to share experiences about their tasks and work. It enables employees to share knowledge and a mental model that positively affects task performance and team coordination. Moreover, role teamwork affects knowledge sharing within the team. Research on the learning behavior in workplaces indicates that individuals receive informal learning from peers more than the organization's formal training (Maurer et al., 2003). In this way, knowledge sharing within the team is a cooperative behavior of members and is affected by team cohesiveness. Knowledge sharing between team members is an individual's voluntary and conscious action (Nonaka, 1994).

The findings show that the empowerment of leadership dimensions, knowledge sharing, and team cohesion positively and indirectly affects team performance. Knowledge sharing behavior has a positive mediative effect on the relationship between leadership empowerment and team performance. Also, knowledge sharing behavior positively mediates the relationship between team cohesion and team performance (Kasemsap, 2013). The results reinforce that a cohesive team enables knowledge sharing and task cohesion among members.

Therefore, the hypothesis is formulated:

H5: Cohesion influences Proactive knowledge sharing.

\subsubsection{Cohesion and employee performance}

When team members carry out activities together, such as having lunch or visit one other at home, they familiarize themselves with each other, their relationship becomes stronger, and the team becomes more $\mathrm{COH}$ (Sanders \& Van Emmerik, 2004). Compactness increases team members' energy and commitment to task accomplishment, reducing maintenance requirements. The cohesive team reduces friction between employees and increases employee confidence and coordination among team members
(Dobbins \& Zaccaro, 1986). Task cohesion is concerned with goals, objectives, and collective performance (Carron et al., 1985). Therefore, $\mathrm{COH}$ is related to EP.

Previous research showed that team $\mathrm{COH}$ positively relates to performance. Also, integrated meta-analysis research 49 correlational and experimental studies show that the relationship is relatively small, though it is still significant. Correlational studies show a stronger relationship between performance and team cohesiveness (Mullen \& Copper, 1994). Moreover, regarding the teams distributed globally, perceived trust and team $\mathrm{COH}$ positively correlate with individual performance (Garrison et al., 2010). Team cohesiveness could have an indirect relationship with individual performance (van Woerkom \& Sanders, 2010).

Therefore, the hypothesis is formulated:

H6: Cohesion influences employee performance.

\subsubsection{Proactive knowledge sharing and employee performance}

Knowledge sharing improves performance through better decision-making and coordination. Empirical research found that high knowledge-sharing enhances careful consideration and improved knowledge utilization by the team, resulting in better decision-making (Wittenbaum et al., 2004).

Studies examine the positive effect of knowledge generated through productivity improvement programs on organizational performance (Hansen, 2002; Arthur \& Huntley, 2005; Mesmer-Magnus \& DeChurch, 2009). The studies showed that knowledge sharing implementation reduces unit costs in auto parts manufacturing.

Empirical findings prove that knowledge sharing positively impacts performance through cost reduction, organizational growth, and intangible benefits in the oil and gas sector (Ali et al., 2019).

Therefore, the hypothesis is formulated:

H7: Proactive knowledge sharing influences employee performance.

The empirical research model is developed as follows:

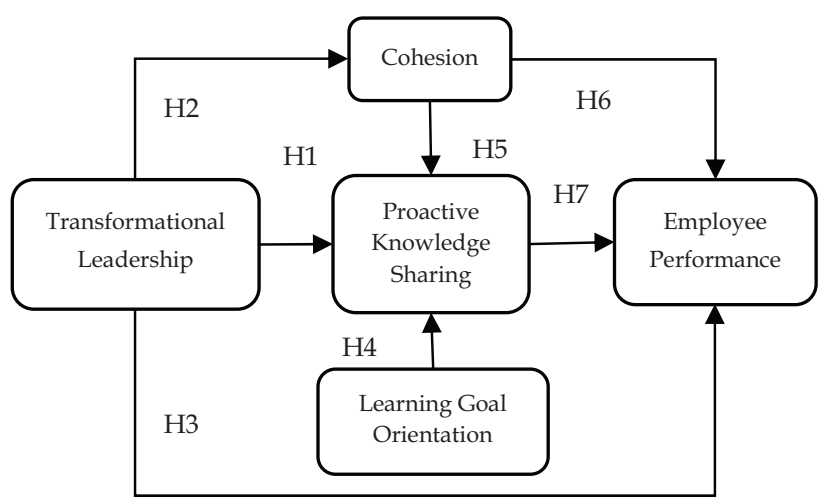

Figure 1. Empirical research model (source: development by authors)

The figure above (Figure 1) illustrates how a PKS model in an organization can be built and mediates the 
relationship between the variables studied. There are three main pillars to build this model. First, leadership. Leadership in an organization functions as the main controller of all activities carried out by the organization. Leaders can build a work climate and culture that will increase employee cohesiveness at work. In addition, a leader can also influence employees by communicating challenging visions, guiding employees and motivating subordinates to realize organizational goals. Thus, a leader in an organization is a leader who is proactive in creating conditions that allow employees to develop skills and knowledge in a workgroup and allows making easy access for all employees to obtain relevant knowledge in the organization.

The second pillar is $\mathrm{COH}$. The selected human resources will have the same vision as the leader and be more cohesive. Cohesion working groups tend to interact more with fellow members, show cooperative behaviour to help and share and have a tendency to communicate freely with fellow team members. This condition allows the proactive sharing of knowledge among members of the work team.

The third is goal orientation. Employees who have a goal orientation at work will show better individual behaviour and performance. Concerning learning, employees who have a LGO will proactively seek knowledge from their surrounding environment. Knowledge can be obtained from work teams, leaders and can also be obtained from other people outside the organization. This knowledge can increase skills and knowledge about their work. These three pillars enable PKS within the organization. PKS has the potential to improve employee skills and work knowledge, the next impact is to improve EP.

\section{Methodology}

The hypotheses were tested by distributing 350 questionnaires to Islamic bank employees in region III Cirebon, Indonesia. Purposive sampling was used to select permanent Islamic banking employees that had worked for at least 2 years, more than 10 years, and Muslims. With these strict requirements, it is hoped that the samples used can be representative. Data were collected using questionnaires with a scale of 10 , with 1 indicating strongly disagree, while 10 showing strongly agree. The questionnaires were adapted from different studies tailored to the object of research.

TL is leadership that requires action to motivate subordinates to work towards high-level goals beyond personal interests (Bass, 1996; García-Morales et al., 2012). This involves giving an example, inspiring actions, providing problem-solving impetus, and paying attention to subordinates.

$\mathrm{COH}$ is the closeness between group members in performing their job duties (Chang \& Bordia, 2001; Carless $\&$ De Paola, 2000). The indicators used are team morale or spirit, social support, workload sharing, and communication or team cooperation.
LGO is the individual orientation to improve and master the tasks undertaken. The indicators used include studying from the task at hand, learning teamwork, and the customer (Sujan et al., 1994).

PKS is the transfer of knowledge from the individual, team or organization by actively contributing to the exchange of explicit and implicit knowledge to improve work performance. The 3 proactive indicators include actively proposing ideas for improving work quality, communicating opinions about work issues to other parties even when their opinions differ or others disagree, and recommending issues affecting the organization (Van Dyne \& LePine, 1998; Grant et al., 2011). The knowledge sharing indicators include shared explicit knowledge of business proposals and reports, manual business models and methodologies, success stories and failures, and business gained from the news, magazines, and journals. Implicit knowledge indicators include sharing work experience, sharia knowledge mastered by each (tacit)), and the expertise gained from education and training (tacit)) (Lee, 2001; Yang \& Chen, 2007).

EP is a task officially recognized as part of the work and contributes to the organization's technical core. The indicators used include producing high-proactive to complete all core tasks on time and ensuring all the work meets the formal requirements (Williams \& Anderson, 1991). The data collected was analyzed using Structural Equation Modeling (SEM). SEM is a statistical tool used to solve multilevel models simultaneously which cannot be solved by linear regression equations.

\section{Results and discussion}

This section contains the following. Part one outlines the interesting findings regarding the respondent while part two examines the hypothesis, part three describes the analysis of the mediating factors. Finally, this paper suggests conclusions and implications.

\subsection{Descriptive statistics}

Respondents in this study were employees of Islamic banking from Cirebon Region, Indonesia, which covers the city of Cirebon and Indramayu, Majalengka and Kuningan districts. The study was conducted by distributing 350 questionnaires allocated proportionally. However, 177 questionnaires did not qualify, while 21 were not answered by filling in all the required information. Therefore, only 156 samples from the respondents were analyzed. From this number, Bank Mandiri Syariah was represented by $23.08 \%$, BNI Syariah by $13.46 \%$, BRI Syariah by $15.38 \%$, BJB Syariah by $16.67 \%$, Bank Muamalat by $19.23 \%$, and BTN Syariah by $12.18 \%$.

After initial checking, 30 questionnaires collected were tested for their validity and reliability using SPSS 20.0 software. The results are shown in Table 1. 
Table 1. Validity and reliability of research instruments

\begin{tabular}{|c|c|c|c|}
\hline Items sample & Correlation & $\begin{array}{c}\text { Cronbach } \\
\text { Alpha }\end{array}$ & Decision \\
\hline $\mathrm{X} 1$ & 0.787 & \multirow{4}{*}{0.876} & \multirow{4}{*}{ Valid and Reliable } \\
\hline $\mathrm{X} 2$ & 0.865 & & \\
\hline $\mathrm{X} 3$ & 0.885 & & \\
\hline $\mathrm{X} 4$ & 0.877 & & \\
\hline $\mathrm{X} 5$ & 0.774 & \multirow{4}{*}{0.820} & \multirow{4}{*}{ Valid and Reliable } \\
\hline $\mathrm{X} 6$ & 0.849 & & \\
\hline $\mathrm{X} 7$ & 0.841 & & \\
\hline $\mathrm{X} 8$ & 0.759 & & \\
\hline X9 & 0.908 & \multirow{3}{*}{0.863} & \multirow{3}{*}{ Valid and Reliable } \\
\hline $\mathrm{X} 10$ & 0.851 & & \\
\hline $\mathrm{X} 11$ & 0.899 & & \\
\hline $\mathrm{X} 12$ & 0.644 & \multirow{10}{*}{0.828} & \multirow{10}{*}{ Valid and Reliable } \\
\hline $\mathrm{X} 13$ & 0.661 & & \\
\hline $\mathrm{X} 14$ & 0.368 & & \\
\hline $\mathrm{X} 15$ & 0.689 & & \\
\hline $\mathrm{X} 16$ & 0.761 & & \\
\hline $\mathrm{X} 17$ & 0.642 & & \\
\hline $\mathrm{X} 18$ & 0.698 & & \\
\hline X19 & 0.590 & & \\
\hline $\mathrm{X} 20$ & 0.749 & & \\
\hline $\mathrm{X} 21$ & 0.514 & & \\
\hline $\mathrm{X} 22$ & 0.930 & \multirow{4}{*}{0.899} & \multirow{4}{*}{ Valid and Reliable } \\
\hline $\mathrm{X} 23$ & 0.937 & & \\
\hline $\mathrm{X} 24$ & 0.715 & & \\
\hline $\mathrm{X} 25$ & 0.907 & & \\
\hline
\end{tabular}

The test results show that all items are valid and reliable.

The interesting fact about the descriptive statistics table (Table 2) is the classification of education. The results showed that the educational background of sharia-based employees was only $8.97 \%$. This result shows the inconsistency of employee competencies required by Islamic banks regarding Islamic knowledge.

\subsection{Hypothesis testing and discussion}

The results of data processing with AMOS shows that the loading factor of several indicators of the PKS variable with a value below 0.5 is $\mathrm{X} 14, \mathrm{x} 15, \mathrm{X} 18$, and $\mathrm{X} 21$. The indicators $\mathrm{x} 10, \mathrm{x} 17, \mathrm{x} 19$ and $\mathrm{x} 22$ indicated have crossloading factor.

The indicators are declared invalid as a measure of the construct and dropped out of the analysis to avoid diminishing the concept's substance. The calculation in Table 3 shows that the Variance Extracted and Construct reliability conforms with the requirements (VE $>0.50$ and $\mathrm{CR}>$ $0.70)$. Therefore, the exogenous construct comprising the variable of TL and LGO, and those consisting of endogenous variable $\mathrm{COH}, \mathrm{PKS}$ and $\mathrm{EP}$ have met the required criteria. It means that the indicators making the variable valid explain existing constructs.
Table 2. Descriptive statistics (source: Field data)

\begin{tabular}{|c|c|c|c|}
\hline No. & Description & Amount & Percentage \\
\hline \multirow[t]{3}{*}{1} & Gender & & \\
\hline & Man & 79 & 50.64 \\
\hline & Female & 77 & 49.36 \\
\hline \multirow[t]{5}{*}{2} & Age & & \\
\hline & 20-24 years old & 15 & 9.62 \\
\hline & 25-29 years old & 84 & 53.85 \\
\hline & $30-40$ years old & 54 & 34.62 \\
\hline & $>40$ years & 3 & 1.92 \\
\hline \multirow[t]{5}{*}{3} & Level of education & & \\
\hline & High School & & \\
\hline & Diploma - D3 & 29 & 18.59 \\
\hline & Bachelor degree - S1 & 127 & 81.41 \\
\hline & Bachelor - S2 & & \\
\hline \multirow[t]{3}{*}{4} & Classification of Education & & \\
\hline & General & 142 & 91.03 \\
\hline & Sharia & 14 & 8.97 \\
\hline \multirow[t]{3}{*}{5} & Years of Work & & \\
\hline & $2-5$ years & 125 & 80.13 \\
\hline & $>5$ years & 31 & 19.87 \\
\hline \multirow[t]{7}{*}{6} & Work experience & & \\
\hline & Bank or Financial Institution & \multirow{2}{*}{22} & \multirow{2}{*}{14.10} \\
\hline & Not a Conventional Bank & & \\
\hline & Bank or Financial Institution & \multirow{2}{*}{37} & \multirow{2}{*}{23.72} \\
\hline & Not Islamic Bank & & \\
\hline & Unprecedented Working in & \multirow{2}{*}{97} & \multirow{2}{*}{62.18} \\
\hline & Banking or LKBB & & \\
\hline
\end{tabular}

Table 3. CFA, VE and CR indicators research variables (source: these results are adapted from statistical outputs AMOS)

\begin{tabular}{|c|c|c|}
\hline Item & Indicator & \\
\hline \multicolumn{3}{|l|}{ TL } \\
\hline $\mathrm{X} 1$ & The act of giving an example & 0.878 \\
\hline $\mathrm{X} 2$ & Actions inspire & 0.860 \\
\hline $\mathrm{X} 3$ & $\begin{array}{l}\text { The act of giving impetus to solve the } \\
\text { problem }\end{array}$ & 0.717 \\
\hline \multirow[t]{3}{*}{$\mathrm{X} 4$} & $\begin{array}{l}\text { The act of giving attention to the } \\
\text { subordinate }\end{array}$ & 0.862 \\
\hline & Variance Extract & 0.834 \\
\hline & Construct Reliability & 0.901 \\
\hline \multicolumn{3}{|l|}{$\mathrm{COH}$} \\
\hline $\mathrm{X} 5$ & Team morale/spirit & 0.610 \\
\hline X6 & Social support & 0.857 \\
\hline $\mathrm{X} 7$ & Workload sharing & 0.732 \\
\hline \multirow[t]{3}{*}{$\mathrm{X} 8$} & $\begin{array}{l}\text { Communication/cooperation within a } \\
\text { team }\end{array}$ & 0.789 \\
\hline & Variance Extract & 0.752 \\
\hline & Construct Reliability & 0.837 \\
\hline \multicolumn{3}{|l|}{ LGO } \\
\hline X9 & Learning from the task at hand & 0.878 \\
\hline
\end{tabular}


End of Table 3

\begin{tabular}{|c|c|c|}
\hline Item & Indicator & \\
\hline \multirow[t]{3}{*}{$\mathrm{X} 11$} & Learning from customers & 0.899 \\
\hline & Variance Extract & 0.883 \\
\hline & Construct Reliability & 0.914 \\
\hline \multicolumn{3}{|l|}{ PKS } \\
\hline $\mathrm{X} 12$ & $\begin{array}{l}\text { actively put forward ideas for } \\
\text { improvement in the quality of work } \\
\text { procedures }\end{array}$ & 0.791 \\
\hline $\mathrm{X} 13$ & $\begin{array}{l}\text { active communication opinions about } \\
\text { work issues, on the other hand, even if } \\
\text { their opinions differ or others disagree }\end{array}$ & 0.706 \\
\hline $\mathrm{X} 16$ & $\begin{array}{l}\text { sharing knowledge } \\
\text { of manual business, models, and } \\
\text { methodologies (explicit knowledge) }\end{array}$ & 0.864 \\
\hline \multirow[t]{3}{*}{$\mathrm{X} 20$} & $\begin{array}{l}\text { sharing knowledge of Sharia, each } \\
\text { master (implicit knowledge(tacit)) }\end{array}$ & 0.614 \\
\hline & Variance Extract & 0.730 \\
\hline & Construct Reliability & 0.871 \\
\hline \multicolumn{3}{|l|}{ EP } \\
\hline $\mathrm{X} 22$ & Produce high- quality work & 0.804 \\
\hline $\mathrm{X} 23$ & $\begin{array}{l}\text { Proficient completes all core tasks of } \\
\text { work }\end{array}$ & 0.869 \\
\hline $\mathrm{X} 24$ & $\begin{array}{l}\text { Complete homework assignments on } \\
\text { time }\end{array}$ & 0.661 \\
\hline \multirow[t]{3}{*}{$\mathrm{X} 25$} & $\begin{array}{l}\text { All of the work under the formal } \\
\text { requirements }\end{array}$ & 0.878 \\
\hline & Variance Extract & 0.808 \\
\hline & Construct Reliability & 0.881 \\
\hline
\end{tabular}

The SEM evaluation results comprising sample adequacy, normality, and outliers showed that the empirical research's full SEM model met the SEM assumption. Furthermore, suitability and statistical tests were performed on the full SEM model. The results showed that the overall empirical research model fit with observation or was well categorized. The Chi-Square value, significance probability (p-value), GFI, RMSEA, CMIN or DF, CFI, TLI, PNFI and PCFI meet the goodness of fit criteria. In contrast, AGFI meets the suggested cut-off value, albeit marginally acceptable.

Hypothesis testing is based on the output end of the full SEM model of empirical research. Regression weight gives the unstandardized and standardized coefficient values for the OLS regression equation (Ghozali, 2011). CR value is equal to the value of $t$ on OLS regression, while $\mathrm{P}$ equals the significance probability. Table 4 shows that regression weight is determined by acceptance or rejection of the hypothesis or the relationship between the two latent variables.

An analysis was conducted on the empirical SEM model of all hypotheses relating to PKS. The results showed that hypotheses $1,2,4,5$ and 7 were significantly accepted, with a 95\% confidence level, while hypotheses 3 and 6 were rejected. The acceptance of hypothesis 5 confirms that the new PKS concept solves the study contradiction between TL and EP.
Table 4. Regression weights SEM above hypothesis interpersonal variables (source: AMOS output)

\begin{tabular}{|l|c|c|c|c|c|c|}
\hline \multicolumn{2}{|c|}{$\begin{array}{c}\text { Relationships between } \\
\text { latent variables in the } \\
\text { model }\end{array}$} & Estimate & SE & CR & P \\
\hline COH & $<---$ & TL & 0.128 & 0.059 & 2.182 & 0.029 \\
\hline PKS & $<---$ & TL & 0.235 & 0.088 & 2.686 & 0.007 \\
\hline PKS & $<---$ & LGO & 0.251 & 0.081 & 3.091 & 0.002 \\
\hline PKS & $<---$ & COH & 0.676 & 0.163 & 4.147 & $* * *$ \\
\hline EP & $<---$ & PKS & 0.372 & 0.118 & 3.156 & 0.002 \\
\hline EP & $<---$ & COH & -0.001 & 0.199 & -0.004 & 0.997 \\
\hline EP & $<---$ & TL & -0.032 & 0.106 & -0.302 & 0.762 \\
\hline
\end{tabular}

Parameter estimation showed TL's influence on the EP of -0.030 with a significance value at $\mathrm{CR}=-0.302$ below the required $C R \geq 2.00$, with a significance level of 0.01 (1\%). Therefore, hypothesis 3 is rejected and cannot be proven. These results differ from (Buil et al., 2019; Ribeiro et al., 2018; Obeidat \& Tarhini, 2016; Asrar-ul-Haq \& Kuchinke, 2016; Cavazotte et al., 2013; Sundi, 2013; Carter et al., 2013; Ghafoor et al., 2011), which showed that TL influences EP. This difference leads to contradictory results. Furthermore, different values in each company that the employee works for cause disparities in the results showing that TL indirectly affects EP through other mechanisms.

Parameter estimation showed the effect of $\mathrm{COH}$ on EP of 0.000 , with a significance value of $\mathrm{CR}=-0.004$ under $\mathrm{CR} \geq 2.00$, with a significance level of $0.01(1 \%)$. Therefore, hypothesis 6 is rejected and not proven.

\subsection{Mediating factor analysis}

The Sobel test is used to assess the significance of indirect or mediating effects on the structural equation model (Sobel, 1982). Figure 2 presents the Sobel Test calculation results regarding the PKS' mediating role in TL's EP effect.

Figure 2 shows that the Sobel Test Statistic is 2.037 with a one-tailed probability of 0.020 and a two-tiled probability of 0.041 with a significance of $p=0.05$. These results confirm that PKS is essential in overcoming the research gap regarding TL's effect on EP.

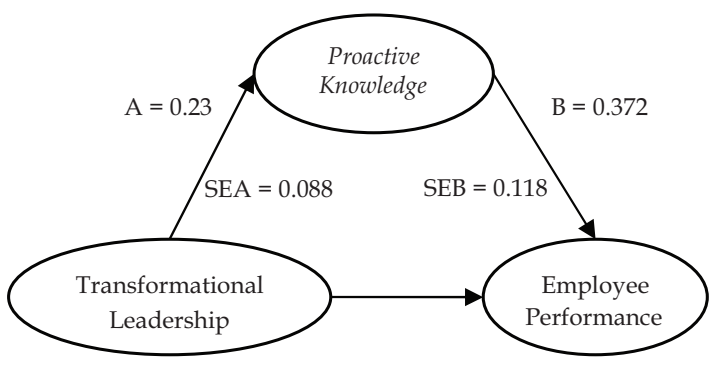

Sobel Test Statistic: 2.03765784

one-tiled probability: 0.02079208

two-tiled probability: 0.04158416

Figure 2. Mediation factor between employee performance and transformational leadership (source: development by authors) 


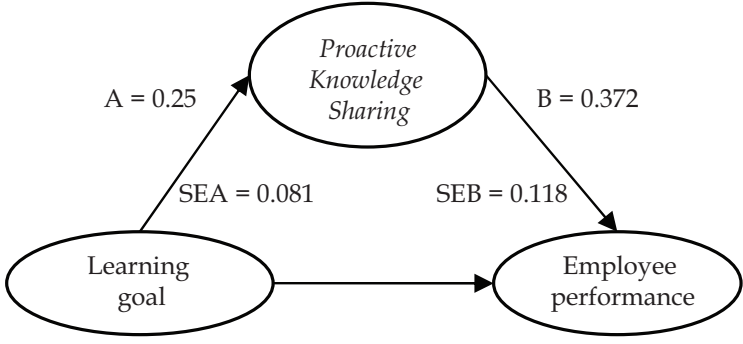

Sobel Test Statistic: 2.20992574

one-tiled probability: 0.01355516

two-tiled probability: 0.02711032

Figure 3. Mediation factor between employee performance and learning goal orientation (source: development by authors)

Figure 3 shows the role of PKS in mediating the effect of LGO on EP. The results show that PKS significantly mediates the relationship between employee performance and learning goal orientation, which is in line with the two previous mediations. Figure 4 shows that PKS significantly mediates the effect of $\mathrm{COH}$ on EP.

The findings support empirical research that TL motivates and inspires employees to share their knowledge (Bradshaw et al., 2015). In line with this, there are several ways for Islamic banking to improve EP. These pathways explain the relationship between the variables constructed in this study, which could improve the EP.

First, EP is characterized by work quality, timely completion of all core tasks, and working according to formal requirements. One way to improve EP is by implementing a TL style that moves the PKS fellow employees to generate high EP.

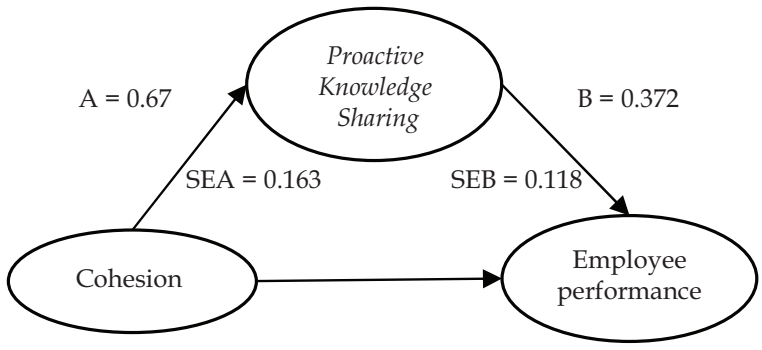

Sobel Test Statistic: 2.50974830

one-tiled probability: 0.00604086 two-tiled probability: 0.01208172

Figure 4. Mediation factor between cohesion orientation and employee performance (source: development by authors)

A transformational leader creates a model tailored to the employees' willingness to share their knowledge and continue learning and searching for new ideas. Moreover, an organization's leader creates a climate that allows and facilitates the sharing of knowledge. Transformational leaders contribute to knowledge through a shared vision, providing a suitable model, encouraging adaptation to the group's goals, and inspiring employees. Additionally, the leaders support innovative ideas, build systems and culture, and share the knowledge that ultimately improves employee performance.
Second, EP is improved through the role of transformational leaders in which the team works cohesively. $\mathrm{COH}$ in work enhances the implementation of the work activities together. This joint activity is carried out with intensive communication among colleagues by sharing each employee's knowledge, enabling PKS to complete all tasks.

A transformational leader designs and builds a working group to instil the personal values of employees. These values are internalized, cooperated, and harmonized between employees based on the transformational leader's vision. The collective vision is developed within the group, which increases the $\mathrm{COH}$.

One of the most fundamental aspects of teamwork is $\mathrm{COH}$. Cohesive teamwork interacts more, readily agrees on anything and works in coordination. Team members behave cooperatively and assist one other because of the stronger ties binding them together. As a result, sharing knowledge with team members is an individual's voluntary and conscious act. Therefore, the $\mathrm{COH}$ within the team is essential in sharing knowledge.

Knowledge sharing proactively assists in creating and developing shared mental models and transactive memory of fellow workers, improving coordination between team members. As a result, job performance increases due to a favorable effect of team coordination.

Third, EP could be improved by emphasizing the importance of learning to employees. An employee that wants to learn is employee-oriented learning objectives. LGO affects the activity of proactive knowledge sharing and improves performance.

The control theory regarding the purpose of the orientation framework shows that the difference between the objectives desired and the actions taken motivates resolving the disparities and stimulates self-regulation. LGO significantly affects the learning process and employees' knowledge sharing behavior because of their personal goals and the motivation to act.

More learning-oriented employees are involved in knowledge sharing because they are interested in developing the skills and knowledge for themselves and their colleagues. This increases their skills and abilities, such as knowledge and self-efficacy, which improves work efficiency and productivity.

\section{Conclusions}

This study indicates that there are other mechanisms of TL relationships and EP. Moreover, the results revealed the significance of the mediating variable PKS in reinforcing the relationship between TL and EP, an indication this research fills the previous theoretical gap. Therefore, employees improve their performance through PKS. Also, transformational leaders could improve the subordinates' performance by motivating them to share knowledge, improve employee cohesion and be oriented towards learning. These results show that the sharia knowledge of employees could be increased through PKS. 


\section{Theoretical implications}

In this study, PKS is a novelty variable that mediates TL, $\mathrm{COH}$ and LGO on EP. These results support previous studies that the relationship of TL, $\mathrm{COH}$ on $\mathrm{EP}$ is indirect. Therefore, future research should apply this novelty variable with other variables, such as organizational culture, which is not implemented in this study.

\section{Managerial implications}

Islamic banking practitioners must increase PKS activities that affect EP. These results indicate that most Syariah banking employees have a general education background, meaning they are not from Syariah-based colleges. Therefore, proactive sharing of Sharia knowledge is necessary. PKS in Sharia knowledge could be conducted through formal and informal meetings.

\section{Limitations}

The data obtained affect the results' quality, though this could be prevented through complete instrument testing. This happens because the level of employee work in the banking sector makes the respondents' answers inaccurate. Moreover, it is essential to fill out the questionnaires quickly, though this results in inaccurate and dishonest answers from respondents. Therefore, these results need to be generalized with care because this research was conducted on employees with different cultures in managing work-life in each of the 6 Syariah banks.

\section{References}

Akpotu, C., \& Tamunosiki-Amadi, J. (2013). Transformational leadership and knowledge sharing in ICT based organizations in Nigeria. International Journal of Business and Social Science, 4(12), 100-107.

Akram, F., \& Bokhari, R. (2011). The role of knowledge sharing on individual performance, considering the factor of motivation-the conceptual framework. International Journal of Multidisciplinary Sciences and Engineering, 2(9), 44-48.

Aldulaimi, S. (2015). Exploring the effect of organizational culture, leadership and strategy on organizational effectiveness with mediating effect of knowledge management. International Journal of Economics, Commerce and Management, 3(4), 121-132.

Ali, A. A., Paris, L., Selvam, D. D. D. P.,\& Gunasekaran, A. (2019). Key factors influencing knowledge sharing practices and its relationship with organizational performance within the oil and gas industry. Journal of Knowledge Management, 23(9). https://doi.org/10.1108/JKM-06-2018-0394

Amabile, T. M., Schatzel, E. A., Moneta, G. B., \& Kramer, S. J. (2004). Leader behaviors and the work environment for creativity: Perceived leader support. The Leadership Quarterly, 15(1), 5-32. https://doi.org/10.1016/j.leaqua.2003.12.003

Antonakis, J., Avolio, B. J., \& Sivasubramaniam, N. (2003). Context and leadership: An examination of the nine-factor full-range leadership theory using the multifactor leadership questionnaire. The Leadership Quarterly, 14(3), 261-295. https://doi.org/10.1016/S1048-9843(03)00030-4
Arthur, J. B., \& Huntley, C. L. (2005). Ramping up the organizational learning curve: Assessing the impact of deliberate learning on organizational performance under gainsharing. Academy of Management Journal, 48(6), 1159-1170. https://doi.org/10.5465/amj.2005.19573115

Asrar-ul-Haq, M., \& Kuchinke, K. P. (2016). Impact of leadership styles on employees' attitude towards their leader and performance: Empirical evidence from Pakistani banks. Future Business Journal, 2(1), 54-64. https://doi.org/10.1016/j.fbj.2016.05.002

Bashir, M., \& Farooq, R. (2019). The synergetic effect of knowledge management and business model innovation on firm competence. International Journal of Innovation Science, 11(3). https://doi.org/10.1108/IJIS-10-2018-0103

Bass, B. M. (1985). Leadership: Good, better, best. Organizational Dynamics, 13(3), 26-40.

https://doi.org/10.1016/0090-2616(85)90028-2

Bass, B. M. (1995). Comment: Transformational leadership: Looking at other possible antecedents and consequences. Journal of Management Inquiry, 4(3), 293-297. https://doi.org/10.1177/105649269543010

Bass, B. M. (1996). A new paradigm of leadership: An inquiry into transformational leadership. U.S. Army Research Institute for the Behavioral and Social Sciences.

https://doi.org/10.21236/ADA306579

Bass, B. M. (1999). Two decades of research and development in transformational leadership. European Journal of Work and Organizational Psychology, 8(1), 9-32. https://doi.org/10.1080/135943299398410

Baytok, A., Kurt, M., \& Zorlu, Ö. (2014). The role of transformational leader on knowledge sharing practices: A study about international hotel chains. European Journal of Business and Management, 6(7), 46-61.

Borman, W. C., Penner, L. A., Allen, T. D., \& Motowidlo, S. J. (2001). Personality predictors of citizenship performance. International Journal of Selection and Assessment, 9(1-2), 52-69. https://doi.org/10.1111/1468-2389.00163

Bradshaw, R., Chebbi, M., \& Oztel, H. (2015). Leadership and knowledge sharing. Asian Journal of Business Research, (Special Issue 2015). https://doi.org/10.14707/ajbr.150001

Brown, E. A., \& Arendt, S. W. (2010). Perceptions of transformational leadership behaviors and subordinates' performance in hotels. Journal of Human Resources in Hospitality \& Tourism, 10(1), 45-59. https://doi.org/10.1080/15332845.2010.500205

Buil, I., Martínez, E., \& Matute, J. (2019). Transformational leadership and employee performance: The role of identification, engagement and proactive personality. International Journal of Hospitality Management, 77, 64-75. https://doi.org/10.1016/j.ijhm.2018.06.014

Burns, J. M. (1978). Transformational leadership theory. In Leadership. Harper and Row.

Calantone, R. J., Cavusgil, S. T., \& Zhao, Y. (2002). Learning orientation, firm innovation capability, and firm performance. Industrial Marketing Management, 31(6), 515-524. https://doi.org/10.1016/S0019-8501(01)00203-6

Callow, N., Smith, M. J., Hardy, L., Arthur, C. A., \& Hardy, J. (2009). Measurement of transformational leadership and its relationship with team cohesion and performance level. Journal of Applied Sport Psychology, 21(4), 395-412. https://doi.org/10.1080/10413200903204754

Carless, S. A., \& De Paola, C. (2000). The measurement of cohesion in work teams. Small Group Research, 31(1), 71-88. https://doi.org/10.1177/104649640003100104 
Carron, A. V, Brawley, L. R., \& Widmeyer, W. N. (1998). The measurement of cohesiveness in sportgroups. Canadian Journal of Sport Sciences, 14(1), 55-59.

Carter, M. Z., Armenakis, A. A., Feild, H. S., \& Mossholder, K. W. (2013). Transformational leadership, relationship quality, and employee performance during continuous incremental organizational change. Journal of Organizational Behavior, 34(7), 942-958. https://doi.org/10.1002/job.1824

Cavazotte, F., Moreno, V., \& Bernardo, J. (2013). Transformational leaders and work performance: The mediating roles of identification and self-efficacy. BAR-Brazilian Administration Review, 10(4), 490-512. https://doi.org/10.1590/S1807-76922013000400007

Chang, A., \& Bordia, P. (2001). A multidimensional approach to the group cohesion-group performance relationship. Small Group Research, 32(4), 379-405. https://doi.org/10.1177/104649640103200401

Charlton, R., \& Eschleman, K. J. (2019). Person-group fit moderating the transformational leadership contextual performance relationship. Academy of Management Proceedings, 2019(1), 18624. https://doi.org/10.5465/AMBPP.2019.198

Chen, L. Y., \& Barnes, F. B. (2006). Leadership behaviors and knowledge sharing in professional service firms engaged in strategic alliances. Journal of Applied Management and Entrepreneurship, 11(2), 51.

Chen, X.-P., Eberly, M. B., Chiang, T.-J., Farh, J.-L., \& Cheng, B.-S. (2014). Affective trust in Chinese leaders: Linking paternalistic leadership to employee performance. Journal of Management, 40(3), 796-819. https://doi.org/10.1177/0149206311410604

Cooke, F. L., Wang, J., \& Bartram, T. (2019). Can a supportive workplace impact employee resilience in a high pressure performance environment? An investigation of the Chinese banking industry. Applied Psychology, 68(4), 695-718. https://doi.org/10.1111/apps.12184

Cronin, L. D., Arthur, C. A., Hardy, J., \& Callow, N. (2015). Transformational leadership and task cohesion in sport: The mediating role of inside sacrifice. Journal of Sport and Exercise Psychology, 37(1), 23-36.

https://doi.org/10.1123/jsep.2014-0116

DeShon, R. P., \& Gillespie, J. Z. (2005). A motivated action theory account of goal orientation. Journal of Applied Psychology, 90(6), 1096-1127.

https://doi.org/10.1037/0021-9010.90.6.1096

Din, N., \& Haron, S. (2012). Knowledge sharing as a culture among Malaysian online social networking users. Procedia Social and Behavioral Sciences, 50, 1043-1050.

https://doi.org/10.1016/j.sbspro.2012.08.104

Dobbins, G. H., \& Zaccaro, S. J. (1986). The effects of group cohesion and leader behavior on subordinate satisfaction. Group \& Organization Management, 11(3), 203-219. https://doi.org/10.1177/105960118601100305

Donate, M. J., \& de Pablo, J. D. S. (2015). The role of knowledgeoriented leadership in knowledge management practices and innovation. Journal of Business Research, 68(2), 360-370. https://doi.org/10.1016/j.jbusres.2014.06.022

Eliyana, A., \& Ma'arif, S. (2019). Job satisfaction and organizational commitment effect in the transformational leadership towards employee performance. European Research on Management and Business Economics, 25(3), 144-150. https://doi.org/10.1016/j.iedeen.2019.05.001

Ganguly, A., Talukdar, A., \& Chatterjee, D. (2019). Evaluating the role of social capital, tacit knowledge sharing, knowledge quality and reciprocity in determining innovation capability of an organization. Journal of Knowledge Management, 23(6). https://doi.org/10.1108/JKM-03-2018-0190
García-Morales, V. J., Jiménez-Barrionuevo, M. M., \& Gutiérrez-Gutiérrez, L. (2012). Transformational leadership influence on organizational performance through organizational learning and innovation. Journal of Business Research, 65(7), 1040-1050. https://doi.org/10.1016/j.jbusres.2011.03.005

Garrison, G., Wakefield, R. L., Xu, X., \& Kim, S. H. (2010). Globally distributed teams: The effect of diversity on trust, cohesion and individual performance. ACM SIGMIS Database: The Database for Advances in Information Systems, 41(3), 27-48. https://doi.org/10.1145/1851175.1851178

Ghafoor, A., Qureshi, T. M., Khan, M. A., \& Hijazi, S. T. (2011). Transformational leadership, employee engagement and performance: Mediating effect of psychological ownership. African Journal of Business Management, 5(17), 7391-7403. https://doi.org/10.5897/AJBM11.126

Ghozali, I. (2011). Model Persamaan Struktural; Konsep dan Aplikasi dengan Program AMOS 19,0. Badan Penerbit Universitas Diponegoro.

Grant, A. M., Gino, F., \& Hofmann, D. A. (2011). Reversing the extraverted leadership advantage: The role of employee proactivity. Academy of Management Journal, 54(3), 528-550. https://doi.org/10.5465/amj.2011.61968043

Hansen, M. T. (2002). Knowledge networks: Explaining effective knowledge sharing in multiunit companies. Organization Science, 13(3), 232-248.

https://doi.org/10.1287/orsc.13.3.232.2771

Heuzé, J.-P., Sarrazin, P., Masiero, M., Raimbault, N., \& Thomas, J.-P. (2006). The relationships of perceived motivational climate to cohesion and collective efficacy in elite female teams. Journal of Applied Sport Psychology, 18(3), 201-218. https://doi.org/10.1080/10413200600830273

Insan, A. N., Astuti, E. S., Raharjo, K., Hamid, D., \& Brawijaya, M. (2013). The effect of transformational leadership model on employees' job satisfaction and performance at Perusahaan Listrik Negara (PLN Persero) in South Sulawesi, Indonesia. Information and Knowledge Management, 3(5), 135-142.

Javadi, M. H. M., Zadeh, N. D., Zandi, M., \& Yavarian, J. (2012). Effect of motivation and trust on knowledge sharing and effect of knowledge sharing on employee's performance. International Journal of Human Resource Studies, 2(1), 210. https://doi.org/10.5296/ijhrs.v2i1.1675

June, S., \& Mahmood, R. (2011). The relationship between role ambiguity, competency and person-job fit with the job performance of employees in the service sector SMEs in Malaysia. Business Management Dynamics, 1(2), 79.

Kasemsap, K. (2013). Strategic business management: A practical framework and causal model of empowering leadership, team cohesion, knowledge-sharing behavior, and team performance. Journal of Social and Development Sciences, 4(3), 100-106. https://doi.org/10.22610/jsds.v4i3.740

Khan, N. A., \& Khan, A. N. (2019). What followers are saying about transformational leaders fostering employee innovation via organisational learning, knowledge sharing and social media use in public organisations? Government Information Quarterly, 36(4). https://doi.org/10.1016/j.giq.2019.07.003

Kim, T. T., \& Lee, G. (2013). Hospitality employee knowledgesharing behaviors in the relationship between goal orientations and service innovative behavior. International Journal of Hospitality Management, 34(1), 324-337. https://doi.org/10.1016/j.ijhm.2013.04.009

Lee, J.-N. (2001). The impact of knowledge sharing, organizational capability and partnership quality on IS outsourcing success. Information \& Management, 38(5), 323-335. https://doi.org/10.1016/S0378-7206(00)00074-4 
Lee, P., Gillespie, N., Mann, L., \& Wearing, A. (2010). Leadership and trust: Their effect on knowledge sharing and team performance. Management Learning, 41(4), 473-491. https://doi.org/10.1177/1350507610362036

Lu, L., Lin, X., \& Leung, K. (2012). Goal orientation and innovative performance: The mediating roles of knowledge sharing and perceived autonomy. Journal of Applied Social Psychology, 42(Suppl 41), E180-E197. https://doi.org/10.1111/j.1559-1816.2012.01018.x

Mabey, C., Kulich, C., \& Lorenzi-Cioldi, F. (2012). Knowledge leadership in global scientific research. The International Journal of Human Resource Management, 23(12), 2450-2467. https://doi.org/10.1080/09585192.2012.668386

Matsuo, M. (2019). Effect of learning goal orientation on work engagement through job crafting. Personnel Review, 48(1). https://doi.org/10.1108/PR-11-2017-0346

Matzler, K., \& Mueller, J. (2011). Antecedents of knowledge sharing - Examining the influence of learning and performance orientation. Journal of Economic Psychology, 32(3), 317-329. https://doi.org/10.1016/j.joep.2010.12.006

Maurer, T. J., Weiss, E. M., \& Barbeite, F. G. (2003). A model of involvement in work-related learning and development activity: the effects of individual, situational, motivational, and age variables. Journal of Applied Psychology, 88(4), 707-724. https://doi.org/10.1037/0021-9010.88.4.707

Mesmer-Magnus, J. R., \& DeChurch, L. A. (2009). Information sharing and team performance: A meta-analysis. Journal of Applied Psychology, 94(2), 535-546. https://doi.org/10.1037/a0013773

Mullen, B., \& Copper, C. (1994). The relation between group cohesiveness and performance: An integration. Psychological Bulletin, 115, 210-227. https://doi.org/10.1037/0033-2909.115.2.210

Nguyen, T.-M., Nham, P. T., \& Hoang, V. N. V. (2019). The theory of planned behavior and knowledge sharing: A systematic review and meta-analytic structural equation modelling. VINE Journal of Information and Knowledge Management Systems, 49(1), 76-94. https://doi.org/10.1108/VJIKMS-10-2018-0086

Nonaka, I. (1994). A dynamic theory of organizational knowledge creation. Organization Science, 5(1), 14-37.

https://doi.org/10.1287/orsc.5.1.14

Nybakk, E. (2012). Learning orientation, innovativeness and financial performance in traditional manufacturing firms: a higher-order structural equation model. International Journal of Innovation Management, 16(05), 1250029. https://doi.org/10.1142/S1363919612003873

Obeidat, B. Y., \& Tarhini, A. (2016). A Jordanian empirical study of the associations among transformational leadership, transactional leadership, knowledge sharing, job performance, and firm performance. Journal of Management Development, 35(5). https://doi.org/10.1108/JMD-09-2015-0134

Obiwuru, T. C., Okwu, A. T., Akpa, V. O., \& Nwankwere, I. A. (2011). Effects of leadership style on organizational performance: A survey of selected small scale enterprises in IkosiKetu council development area of Lagos State, Nigeria. Australian Journal of Business and Management Research, 1(7), 100-111. https://doi.org/10.52283/NSWRCA.AJBMR.20110107A11

Paracha, M. U., Qamar, A., Mirza, A., Hassan, I., \& Waqas, H. (2012). Impact of leadership style (transformational \& transactional leadership) on employee performance \& mediating role of job satisfaction. Study of private school (educator) in Pakistan. Global Journal of Management and Business Research, 12(4), 55-64.
Payne, S. C., Youngcourt, S. S., \& Beaubien, J. M. (2007). A metaanalytic examination of the goal orientation nomological net. Journal of Applied Psychology, 92(1), 128-150. https://doi.org/10.1037/0021-9010.92.1.128

Quartey, S. H. (2019). Knowledge and sustainable competitive advantage of the Eyre Peninsula's fishing industry in Australia. Knowledge and Process Management, 26(2), 86-97. https://doi.org/10.1002/kpm.1592

Ribeiro, N., Yücel, İ., \& Gomes, D. (2018). How transformational leadership predicts employees' affective commitment and performance. International Journal of Productivity and Performance Management, 67(9).

https://doi.org/10.1108/IJPPM-09-2017-0229

Salo, N. (2011). Knowledge management in education in Indonesia: An overview. Global Journal of Human Social Science, 11(1).

Sarwar, H., Ishaq, M. I., Amin, A., \& Ahmed, R. (2020). Ethical leadership, work engagement, employees' well-being, and performance: a cross-cultural comparison. Journal of Sustainable Tourism, 28(12), 2008-2026. https://doi.org/10.1080/09669582.2020.1788039

Shamir, B., House, R. J., \& Arthur, M. B. (1993). The motivational effects of charismatic leadership: A self-concept based theory. Organization Science, 4(4), 577-594. https://doi.org/10.1287/orsc.4.4.577

Sobel, M. E. (1982). Asymptotic confidence intervals for indirect effects in structural equation models. Sociological Methodology, 13, 290-312. https://doi.org/10.2307/270723

Sokół, A. (2020). Empirical verification of the importance of economic knowledge in the development of creativity of creative employees. Procedia Computer Science, 176, 1684-1692. https://doi.org/10.1016/j.procs.2020.09.193

Sujan, H., Weitz, B. A., \& Kumar, N. (1994). Learning orientation, working smart, and effective selling. Journal of Marketing, 58(3), 39-52. https://doi.org/10.1177/002224299405800303

Sundi, K. (2013). Effect of transformational leadership and transactional leadership on employee performance of Konawe Education department at Southeast Sulawesi province. International Journal of Business and Management Invention, 2(12), 50-58.

Tahir, H. (2015). Leadership style and organizational performance: A comparative study between transformational and transactional leadership styles. Journal of Business Studies (Formerly Journal of Management \& Social Sciences), 11(2), 257-274. https://doi.org/10.46745/ilma.jbs.2015.11.02.19

Terglav, K., Ruzzier, M. K., \& Kaše, R. (2016). Internal branding process: Exploring the role of mediators in top management's leadership-commitment relationship. International Journal of Hospitality Management, 54, 1-11.

https://doi.org/10.1016/j.ijhm.2015.12.007

Tung, Y.-C., Lin, Y.-P., \& Chang, W.-H. (2019). Differentiated leadership and group performance: The mediating effect of group Cohesion. International Journal of Business and Management, 14(1), 114. https://doi.org/10.5539/ijbm.v14n1p114

Van Dyne, L., \& LePine, J. A. (1998). Helping and voice extrarole behaviors: Evidence of construct and predictive validity. Academy of Management Journal, 41(1), 108-119. https://doi.org/10.5465/256902

van Woerkom, M., \& Sanders, K. (2010). The romance of learning from disagreement. The effect of cohesiveness and disagreement on knowledge sharing behavior and individual performance within teams. Journal of Business and Psychology, 25(1), 139-149. https://doi.org/10.1007/s10869-009-9136-y 
VandeWalle, D. (2003). A goal orientation model of feedbackseeking behavior. Human Resource Management Review, 13(4), 581-604. https://doi.org/10.1016/j.hrmr.2003.11.004

Wang, H.-J., Demerouti, E., \& Le Blanc, P. (2017). Transformational leadership, adaptability, and job crafting: The moderating role of organizational identification. Journal of Vocational Behavior, 100, 185-195. https://doi.org/10.1016/j.jvb.2017.03.009

Wang, H. U. I., Law, K. S., Hackett, R. D., Wang, D., \& Chen, Z. X. (2005). Leader-member exchange as a mediator of the relationship between transformational leadership and followers' performance and organizational citizenship behavior. The Academy of Management Journal, 48(3), 420-432. https://doi.org/10.5465/amj.2005.17407908

Williams, L. J., \& Anderson, S. E. (1991). Job satisfaction and organizational commitment as predictors of of organizational citizenship and in-role behaviors. Journal of Management, 17(3), 601-617. https://doi.org/10.1177/014920639101700305

Wittenbaum, G. M., Hollingshead, A. B., \& Botero, I. C. (2004). From cooperative to motivated information sharing in groups: moving beyond the hidden profile paradigm. Communication Monographs, 71(3), 286-310. https://doi.org/10.1080/0363452042000299894

Wong, K. Y. (2005). Critical success factors for implementing knowledge management in small and medium enterprises.
Industrial Management \& Data Systems, 105(3), 261-279. https://doi.org/10.1108/02635570510590101

Yadav, M., Choudhary, S., \& Jain, S. (2019). Transformational leadership and knowledge sharing behavior in freelancers. Journal of Global Operations and Strategic Sourcing, 12(2). https://doi.org/10.1108/JGOSS-08-2017-0030

Yang, C., \& Chen, L.-C. (2007). Can organizational knowledge capabilities affect knowledge sharing behavior? Journal of Information Science, 33(1), 95-109. https://doi.org/10.1177/0165551506068135

Yusuf, A. A., Layaman, L., \& Wartoyo, W. (2017). Membangun Kekuatan nilai perjanjian syariah Dalam upaya Meningkatkan Kinerja Karyawan Bank Syariah di Indonesia. AKADEMIKA: Jurnal Pemikiran Islam, 22(2), 375-392. https://doi.org/10.32332/akademika.v22i2.814

Zaccaro, S. J., \& Lowe, C. A. (1988). Cohesiveness and performance on an additive task: Evidence for multidimensionality. The Journal of Social Psychology, 128(4), 547-558. https://doi.org/10.1080/00224545.1988.9713774

Zeraati, H., Rajabion, L., Molavi, H., \& Navimipour, N. J. (2019). A model for examining the effect of knowledge sharing and new IT-based technologies on the success of the supply chain management systems. Kybernetes, 49(2). https://doi.org/10.1108/K-06-2018-0280 